\title{
Age-dependent changes in the in-vitro response of a pig Sertoli cell-enriched population to FSH
}

\author{
C. Monet-Kuntz and I. Fontaine \\ Unité 'Endocrinologie de la gamétogenèse'. INRA Station de physiologie de la reproduction, \\ CNRS URA 234, Nouzilly 37380, Monnaie, France
}

\begin{abstract}
Summary. The response of pig Sertoli cell-enriched cultures to FSH was investigated by measuring plasminogen activator (PA) secretion in culture, throughout the nonpubertal and prepubertal periods. Sertoli cell-enriched populations could be isolated from birth until a testicular weight of $56 \mathrm{~g}$. FSH elicited a dose-dependent increase in PA secretion by pig Sertoli cell-enriched cultures. The $\mathrm{ED}_{50}$ was minimal for cells coming from testes weighing 10-22 g, and increased more than 2-fold for cells from heavier testes. This suggests that, at the end of the non-pubertal period, an increased FSH sensitivity is important for initiation of spermatogenesis in this species, and that during the prepubertal period Sertoli cells become less sensitive to FSH. The FSH-stimulated PA secretion increased about 10-fold from a testicular weight of $25 \mathrm{~g}$ onwards, i.e. when primary spermatocytes appear in seminiferous tubules.
\end{abstract}

Keywords: pig; Sertoli cell; FSH; plasminogen activator

\section{Introduction}

The ability of the rat Sertoli cell to respond to gonadotrophic stimulation is not constantly present throughout the life-span of this cell. Indeed, during testicular development, the cell becomes less sensitive to FSH, and all the hormone-dependent secretory activities described in the immature animal are no longer stimulated in the mature Sertoli cell (for a review, see Means et al., 1980).

Unlike the rat, the piglet has a clearly protracted quiescent prepubertal interval after the postnatal period. In the Large White piglet, testicular weight increases slowly until 3 months of age (around $30 \mathrm{~g}$ ). At the end of this 'non-pubertal' period, A spermatogonia are already present, and young primary spermatocytes are just appearing in the seminiferous tubules (Godinho \& Cardoso, 1979). Then a 'prepubertal' period is characterized by a rapid testicular growth, and spermatids appear at 4 months of age (around $100 \mathrm{~g}$ ).

In the piglet, the testicular content of FSH receptor increases exponentially from birth to puberty (Hennen et al., 1982) and the question arises about the evolution of Sertoli cell sensitivity to FSH between birth and puberty in this species.

Isolated immature rat Sertoli cells in culture secrete plasminogen activator (PA) under stimulation by FSH and cAMP (for review, see Parvinen et al., 1986). During post-natal development, the testicular PA concentration increases concomitantly with the appearance of mature spermatogenic cells. Moreover, the sensitivity of the PA response makes it a good tool for FSH bioassay (Combarnous et al., 1984).

In this paper, we investigated the sensitivity of Sertoli cell-enriched cultures to FSH by measuring PA secretion throughout the non-pubertal and prepubertal periods in the pig. 


\section{Materials and Methods}

Animals. Large White piglets were born throughout the year. Testes were removed at ages distributed between 23 and 115 days. As the prepubertal period in the pigs is characterized by a high variability in precocity between animals, we chose to define the growing animals by their testicular weight instead of their age.

Chemicals. Trypsin and $\mathrm{Ca}^{2+}$ - and $\mathrm{Mg}^{2+}$-free Hank's Balanced Salt Solution (HBSS) were obtained from Gibco (Grand Island, NY, USA). DNAse I (Sigma DN-25), trypsin inhibitor (Sigma type I-S) collagenase (Sigma type II-S), bovine insulin, human transferrin, $\mathrm{dl}-\alpha$-tocopherol and fibrinogen fraction I (type IV) were purchased from Sigma Chemical Company (St Louis, MO, USA). Ham's F12 medium without glutamine was obtained from Biopro (Strasbourg, France) and L-glutamine from Merck (Darmstadt, West Germany). Leibovitz's L15 medium was obtained from Serva (Heidelberg, West Germany). Fetal bovine serum was purchased from Biomerieux (Charbonnières les Bains, France) and fetal ovine serum was a gift from P. Durand (Nouzilly, France). Pig FSH (NIH-FSH-Pl) was given by the NIAMDD (Bethesda, MD, USA). The results are expressed in terms of pure pig FSH, given that this latter hormone exhibits a potency of 81 times NIH-FSH-P1.

The 96-well culture plates were purchased from Greiner (Strasbourg, France) and 24-well culture plates from Nunc (Roskilde, Denmark).

Isolation of seminiferous tubule cells. The method of Smith \& Griswold (1981) for the culture of bovine Sertoli cells was adapted for pig testes. Testes were weighed and decapsulated. The tissue was chopped with scissors into pieces $\sim 1 \mathrm{~mm}^{3}$. The chopped tissue was added to 8 volumes (w/v) of a solution of $0 \cdot 25 \%$ trypsin and DNAse I $(2000 \mathrm{U} / 100 \mathrm{ml})$ in $\mathrm{Ca}^{2+}$ - and $\mathrm{Mg}^{2+}$-free Hanks' Balanced Salt Solution (HBSS). For piglets $<50$ days of age, DNAse I concentration needed to be doubled, because of the higher proportion of interstitial cells which release DNA under trypsin action. The mixture was incubated for $30 \mathrm{~min}$ in a $34^{\circ} \mathrm{C}$ water bath with constant shaking ( 75 oscillations/min). The suspension was poured into $50-\mathrm{ml}$ polycarbonate tubes and centrifuged at $430 \mathrm{~g}$ for a time sufficient to sediment the seminiferous tubules (it decreased from $2 \mathrm{~min}$ to $10 \mathrm{sec}$ as the washings proceeded). The supernatant fluid was discarded and the seminiferous tubules were resuspended in the same volume of a $0.034 \%$ trypsin inhibitor solution in HBSS. They were sedimented by centrifugation (see above), and washed twice more with HBSS.

The tubules were resuspended in 8 volumes of a solution of collagenase $(20000$ units/100 ml) and DNAse $(2000 \mathrm{U} / 100 \mathrm{ml})$ in HBSS. They were incubated for $60 \mathrm{~min}$ at $34^{\circ} \mathrm{C}$ with constant shaking. The suspension was centrifuged at $430 \mathrm{~g}$ for $2 \mathrm{~min}$. The supernatant fluid was discarded and aggregates were resuspended in 16 volumes of HBSS and poured through a metal screen to remove large particles. The filtrate was centrifuged at $430 \mathrm{~g}$ for $2 \mathrm{~min}$, and the pellet washed twice more with 16 volumes of HBSS. During the second washing, the suspension was filtered through a $200 \mu \mathrm{m}$ nylon gauze (ZBF, Rüschliken, Switzerland). The filtrate was centrifuged at $430 \mathrm{~g}$ for 2 min and the cell pellet was resuspended in $2 \mathrm{ml} \mathrm{F} 12$ medium.

Culture of a Sertoli cell-enriched population. Cells were diluted in an appropriate volume of culture medium to yield approximately $1.5 \times 10^{6}$ Sertoli cells $/ \mathrm{ml}$. The culture medium used was similar to that described by Speight et al. (1984) and consisted of Ham's F12 medium supplemented with glutamine ( $2 \mathrm{~mm})$, insulin $(10 \mu \mathrm{g} / \mathrm{ml})$, transferrin $(5 \mu \mathrm{g} / \mathrm{ml})$ and vitamin $\mathrm{E}(5 \mu \mathrm{g} / \mathrm{ml})$. Fungizone $(2 \cdot 5 \mu \mathrm{g} / \mathrm{ml})$, penicillin $(100 \mathrm{units} / \mathrm{ml})$ and streptomycin $(100 \mu \mathrm{g} / \mathrm{ml})$ were added. Then 500- $\mu$ l samples of a cell suspension were distributed into 24-well plates (Day 0). The dishes were incubated at $34^{\circ} \mathrm{C}$ in an humidified atmosphere of $95 \%$ air: $5 \% \mathrm{CO}_{2}$.

The cells were cultured for the first $24 \mathrm{~h}$ in the absence of any added serum. During this time, the Sertoli cells attached to the culture plate and began to flatten out, while germinal cells remained free floating in the medium. After $24 \mathrm{~h}$ (Day 1), most germinal cells were discarded by 1-3 washings with HBSS (Fig. 1). Fresh culture medium was added with increasing concentrations of pig FSH. In some experiments, FSH was added immediately after the isolation procedure (Day 0). After culture for $16 \mathrm{~h}$, spent media were collected and frozen at $-20^{\circ} \mathrm{C}$ with $0.01 \% \mathrm{BSA}$ (Lacroix \& Fritz, 1982).

On Day 1, Sertoli cell numbers were determined for each animal in the absence of hormone. The plate was washed with 10 mm-Tris, $\mathrm{pH} \mathrm{7.4,} \mathrm{to} \mathrm{remove} \mathrm{floating} \mathrm{germinal} \mathrm{cells.} \mathrm{The} \mathrm{Sertoli} \mathrm{cells} \mathrm{attached} \mathrm{to} \mathrm{the} \mathrm{plate} \mathrm{and} \mathrm{the} \mathrm{germinal}$ cells stuck to them were removed with a trypsin-EDTA solution $(0 \cdot 1 \%(\mathrm{w} / \mathrm{v})$ trypsin and $1 \mathrm{mM}$-EDTA) and neutralized with an equal volume of serum-supplemented $(7 \cdot 5 \%)$ culture medium. Only cells that were identified as Sertoli cells from their irregular shape and presence of nuclear vesicles were counted, using a haemocytometer.

Plasminogen activator assay. The fibrinolysis assay was similar to that described by Lacroix et al. (1977). ${ }^{125} \mathrm{I}$-labelled fibrinogen was diluted with unlabelled fibrinogen and dried down on 96-well culture plates at a concentration of $5 \mu \mathrm{g}$ fibrinogen and $1 \times 10^{5} \mathrm{c}$.p.m. per well. On the day of the assay, the coated ${ }^{125} \mathrm{I}$-labelled fibrinogen was converted to ${ }^{125} \mathrm{I}$-labelled fibrin by the addition of $100 \mu \mathrm{L} 15$ medium supplemented with $10 \%$ plasminogen-depleted fetal bovine serum, for $3 \mathrm{~h}$ at $37^{\circ} \mathrm{C}$. The medium was removed, and replaced by $100 \mu \mathrm{l}$ Sertoli cell spent culture medium. In all but 'blank' wells, $100 \mu \mathrm{l} \mathrm{L15}$ medium containing $8.3 \%$ acid-treated fetal sheep serum as the source of plasminogen were added. The assay was twice as sensitive when fetal sheep serum was used than when fetal bovine serum was used. The incubation was performed at $37^{\circ} \mathrm{C}$ for $16 \mathrm{~h}$. The supernatants were collected for radioactivity measurement in a 12-well LKB model 1260 Multigamma Counter (LKB Instruments, Rockville, MD, USA). Values 

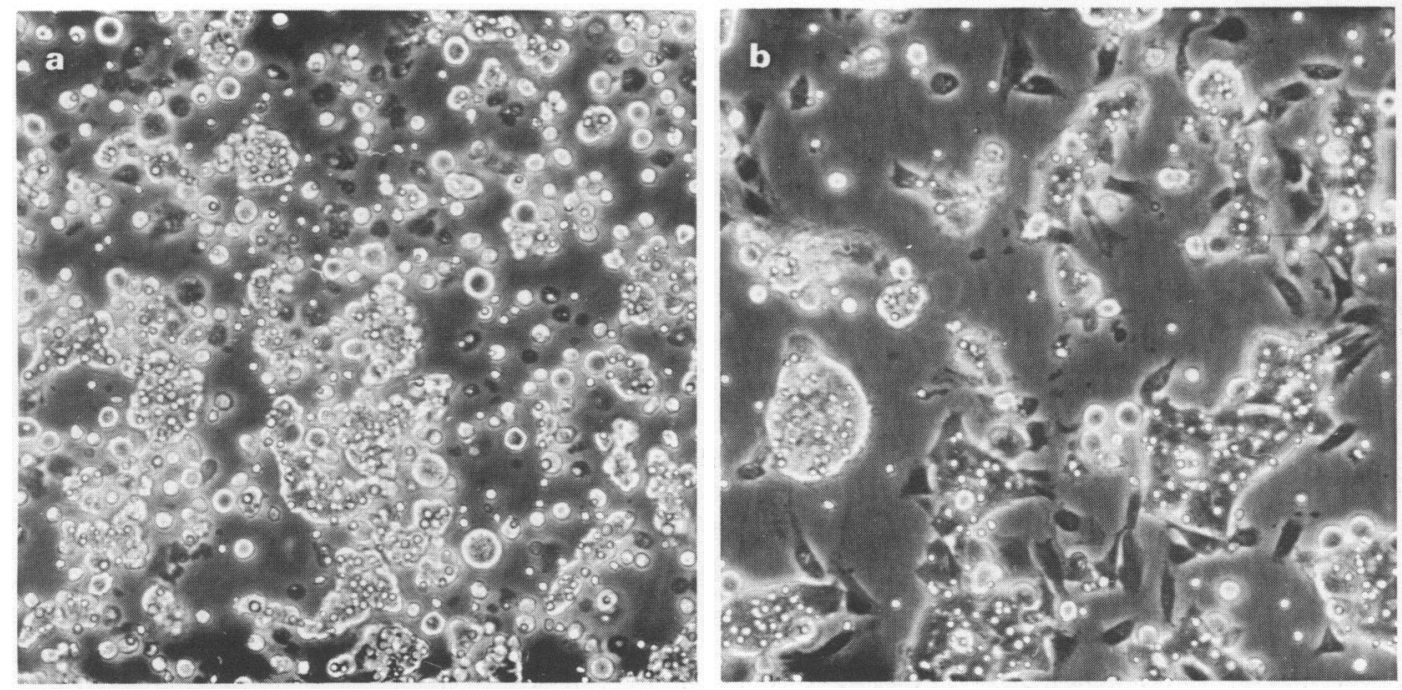

Fig. 1. Phase-contrast micrographs of a seminiferous tubule cell preparation from a piglet testis, on Day 0 (a) or on Day 1 (b) of culture. A cell suspension was prepared from a testis weighing $42 \mathrm{~g}$. In (a), cells were photographed just after seeding (Day 0 of culture). Note the presence of numerous germinal cells in the preparation. In (b), cells were photographed on Day 1 of culture, after 3 washings with HBSS. Note cytoplasmic extensions of Sertoli cells, and decreased number of germinal cells. Such a preparation was named a 'Sertoli cell-enriched culture'. $\times 187$.

for labelled fibrin degradation products released by spent culture medium alone (blank) have been subtracted from values obtained when spent culture medium was assayed in the presence of plasminogen.

A 'PA standard' was prepared in our laboratory. It consisted of spent culture medium from a Sertoli cell-enriched population which had been isolated from a 3-month-old piglet. Cells had been cultured in the presence of pig FSH $(120 \mathrm{ng} / \mathrm{ml})$ and 3-isobutyl-1-methylxanthine (MIX, $\left.10^{-4} \mathrm{M}\right)$. The PA standard yielded fibrinolysis standard curves starting from $3 \times 10^{3}$ c.p.m. and reaching about $6 \times 10^{4}$ c.p.m. per well, which permitted expression of the results of the PA assay as ' $\mu \mathrm{l}$ of standard per ml' of spent culture medium. Our standard curves were parallel to the curve produced by the pure human tPA standard (U83/517, Institute of Biological Standards \& Control, London, UK) (Fig. 2). As the standard curves were steep, spent culture media from FSH dose-response curves had to be assayed at 2 or 3 dilutions. Each dilution was assayed in duplicate.

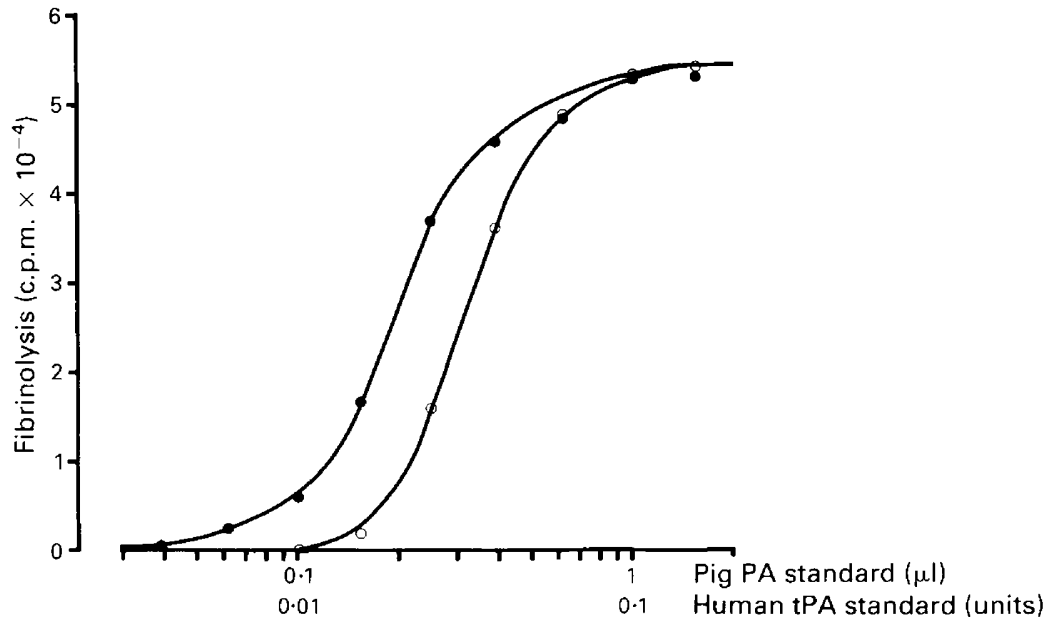

Fig. 2. Fibrinolysis standard curves produced by the internal pig PA standard $(\Theta)$ or by the pure human tPA standard U83/517 $(\bigcirc)$. Values are means for 3 fibrinolysis wells. 
The dose of FSH eliciting 50\% maximal stimulation of PA secretion $\left(\mathrm{ED}_{s 0}\right)$ was determined graphically from individual dose-response curves.

\section{Results}

\section{Isolation of a pig Sertoli cell-enriched population}

The attempt was made to culture FSH-responsive Sertoli cells from piglets from birth until puberty (i.e. appearance of the first spermatozoa in the tubules). As no specific treatment was made to eliminate germ cells, the older the animals, the more seminiferous tubule cells had to be seeded to obtain a constant Sertoli cell density of $3.75 \times 10^{5} / \mathrm{cm}^{2}$. However, even in these seeding conditions, the density of attached Sertoli cells on Day 1 decreased sharply with testis weight of piglets (Fig. 3). No FSH-stimulatable secretion of PA could be detected in spent media of Sertoli cell-enriched cultures from testes heavier than $56 \mathrm{~g}$. Results of PA secretion presented here were obtained with Sertoli cells for which the density ranged between 0.3 and $2.5 \times 10^{5} / \mathrm{cm}^{2}$.

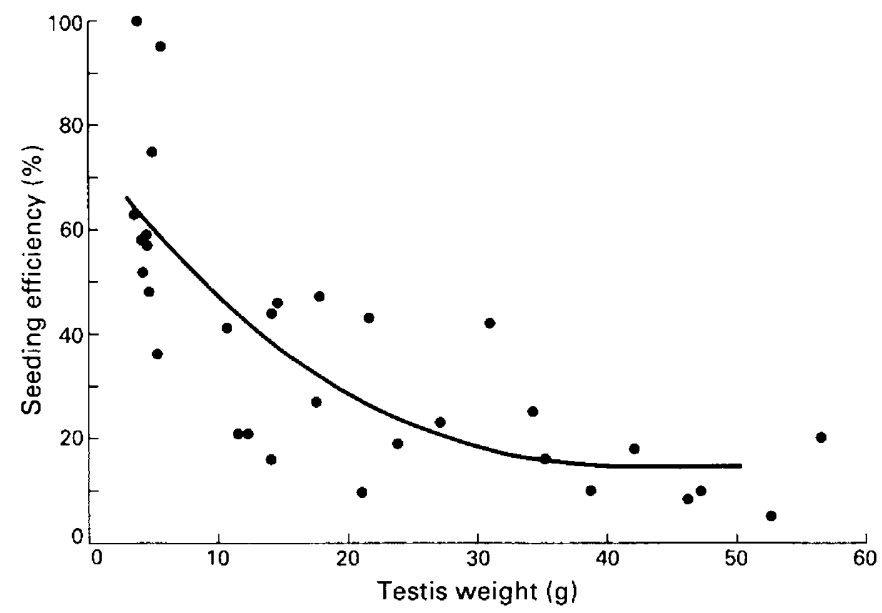

Fig. 3. Efficiency of Sertoli cells seeding as a function of piglet testis weight. Each point represents an animal.

\section{Kinetics of $P A$ secretion}

PA was detectable in the medium $2 \mathrm{~h}$ after FSH addition. Its concentration increased sharply from 4 to $10-12 \mathrm{~h}$, and plateaued until $24 \mathrm{~h}$. The kinetics were similar whether FSH was added on Day 0 (Fig. 4) or on Day 1 of culture (data not shown).

\section{Factors influencing Sertoli cell sensitivity to FSH}

FSH elicited a dose-dependent increase in PA secretion by pig Sertoli cell-enriched cultures (Fig. 5). On average, the dose-response curve extended over a 1-10 range of FSH concentration.

The $\mathrm{ED}_{50}$ varied with the testicular weight of the piglets (Fig. 6). It was minimal for cells coming from testes weighing 10-22 g. Between 10-22 $\mathrm{g}$ and the limiting testicular weight of $56 \mathrm{~g}$, the $\mathrm{ED}_{50}$ increased more than 2 -fold and became more variable. The pattern was similar whether cells were stimulated on Day 0 or on Day 1 of culture.

An influence of piglet testis weight on the density of attached Sertoli cells had been shown. The question therefore arose whether the Sertoli cell sensitivity changes were linked directly to changes in testis physiological stage or, indirectly, via changes in Sertoli cell density. A seminiferous tubule 


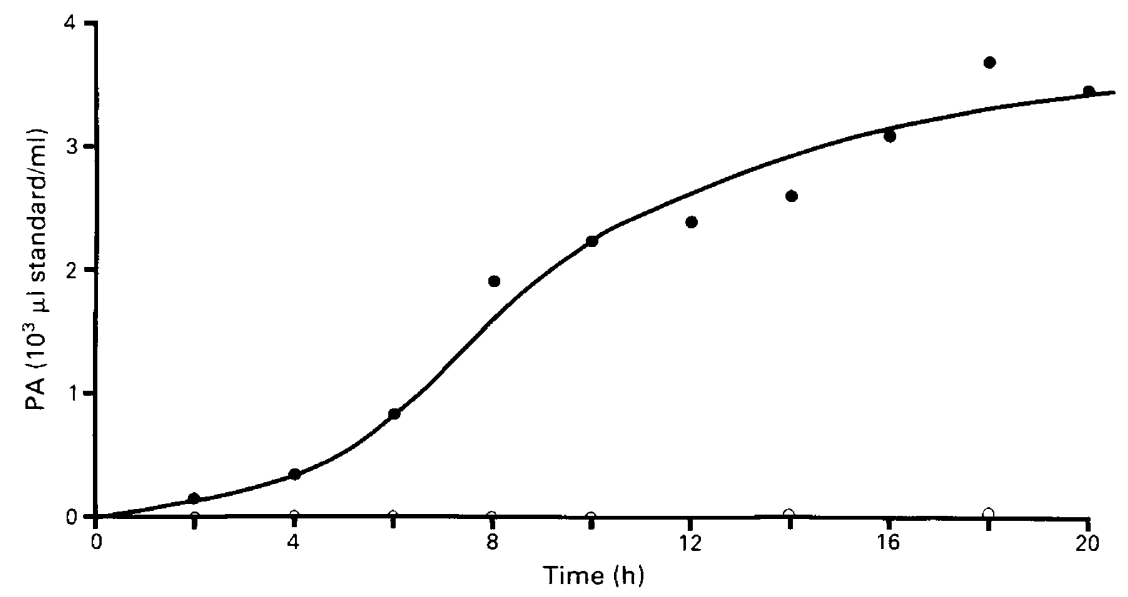

Fig. 4. Kinetics of PA secretion by pig Sertoli cell-enriched cultures. Testis weight $=36 \mathrm{~g}$. Pig FSH $(37 \mathrm{ng} / \mathrm{ml})$ was added $(\bullet)$ or not $(O)$ on Day 0 of culture, and spent medium was collected every $2 \mathrm{~h}$. Values are means for 2 culture wells.

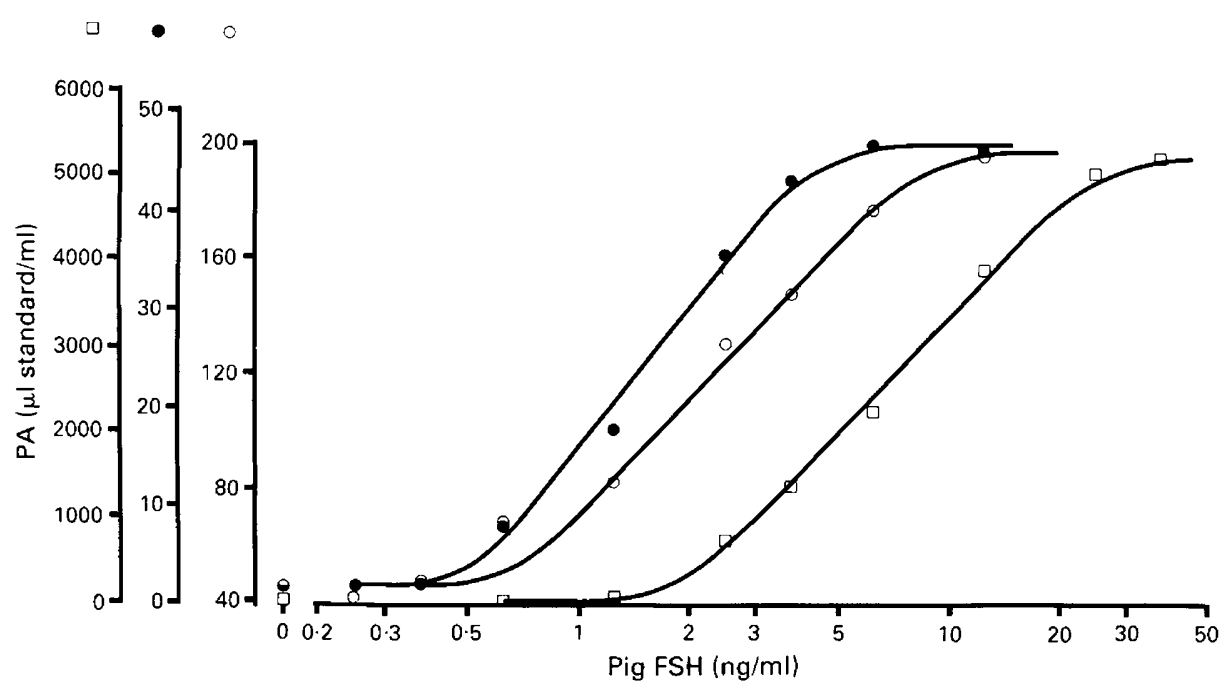

Fig. 5. Influence of piglet testis weight on the response of Sertoli cells to FSH. Seminiferous tubule cell suspensions were prepared from 3 different testes $(O, 3.9 \mathrm{~g} ; \bullet, 11.5 \mathrm{~g} ; \square, 56.5 \mathrm{~g})$. FSH was added on Day 0 of culture, and PA secretion for $16 \mathrm{~h}$ was measured. Values are means for 2 culture wells. The $\mathrm{ED}_{50}$ values are $2 \cdot 4,1.6$ and $6 \cdot 9 \mathrm{ng} \mathrm{FSH} / \mathrm{ml}$ respectively.

cell suspension was therefore diluted at 3 concentrations and stimulated with FSH. Assay of PA in the medium yielded dose-response curves, the $\mathrm{ED}_{50}$ of which were similar: $4.8,6.5$ and $6.6 \mathrm{ng}$ $\mathrm{FSH} / \mathrm{ml}$ for Sertoli cell densities of $0.41,0.96$ and $2.7 \times 10^{5} / \mathrm{cm}^{2}$ respectively (Fig. 7).

\section{Factors influencing the FSH-stimulated PA secretion}

The FSH-stimulated PA secretion varied according to the day of FSH stimulation, since it was 10 times higher on Day 0 than on Day 1 of culture (Fig. 8). This was not due to any positive effect of germinal cells on Sertoli cell PA secretion, since when Sertoli cells were stimulated on Day 1 in the 


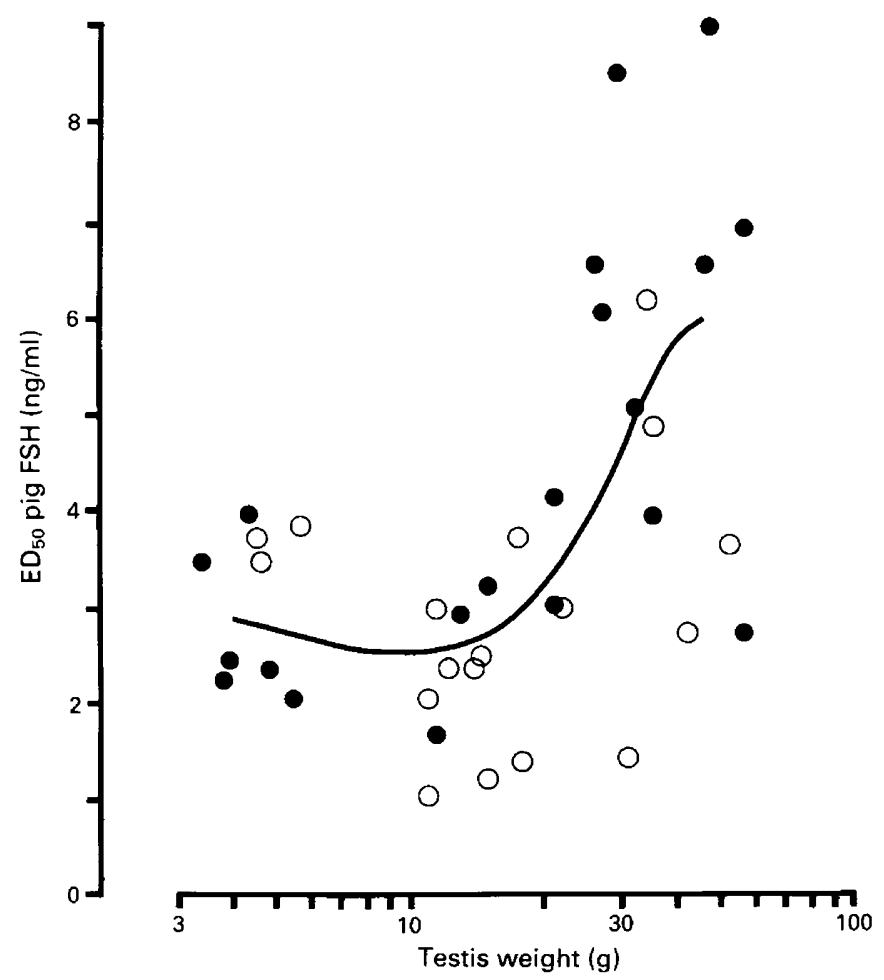

Fig. 6. Dose of FSH producing $50 \%$ of the maximal stimulation of Sertoli cell PA secretion, as a function of the testicular weight of piglets. FSH was added on Day 0 of culture (-) or on Day $1(O)$. Each point represents an animal. Note the logarithmic scale.
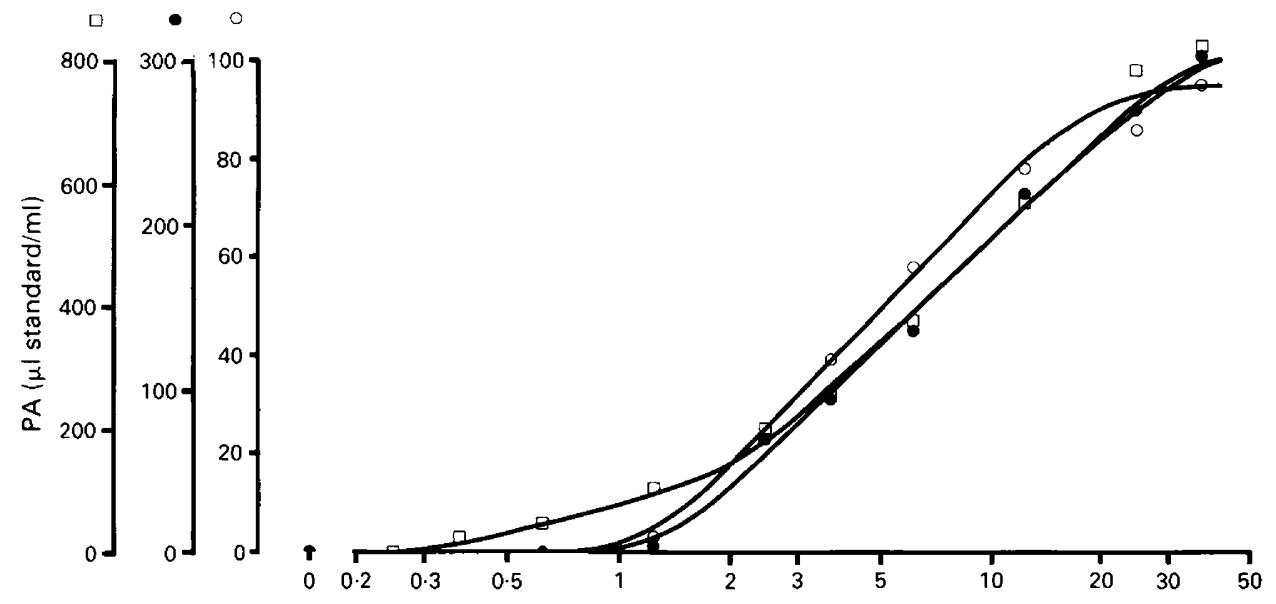

$\mathrm{Pig} \mathrm{FSH}(\mathrm{ng} / \mathrm{ml})$

Fig. 7. Influence of pig Sertoli cell density on their response to FSH. A seminiferous cell suspension from one piglet (testis weight $=26 \mathrm{~g}$ ) was seeded at 3 different concentrations. FSH was added on Day 0 of culture, and PA secretion for $16 \mathrm{~h}$ was measured. On Day 1, Sertoli cell density was determined: $O, 4 \cdot 1 \times 10^{5} / \mathrm{cm}^{2} ; 9.6 \times 10^{5} / \mathrm{cm}^{2} ; \square, 2.7 \times 10^{5} / \mathrm{cm}^{2}$. Values are means for 2 culture wells. 
presence of germinal cells (medium change omitted), the amplitude of stimulation was still much lower than on Day 0 (data not shown).

The FSH-stimulated PA secretion varied markedly according to the testicular weight of the piglets (Fig. 8). It was constant from 3 to $25 \mathrm{~g}$, and then increased about 10 -fold until the limiting testicular weight of $56 \mathrm{~g}$ and became much more variable.

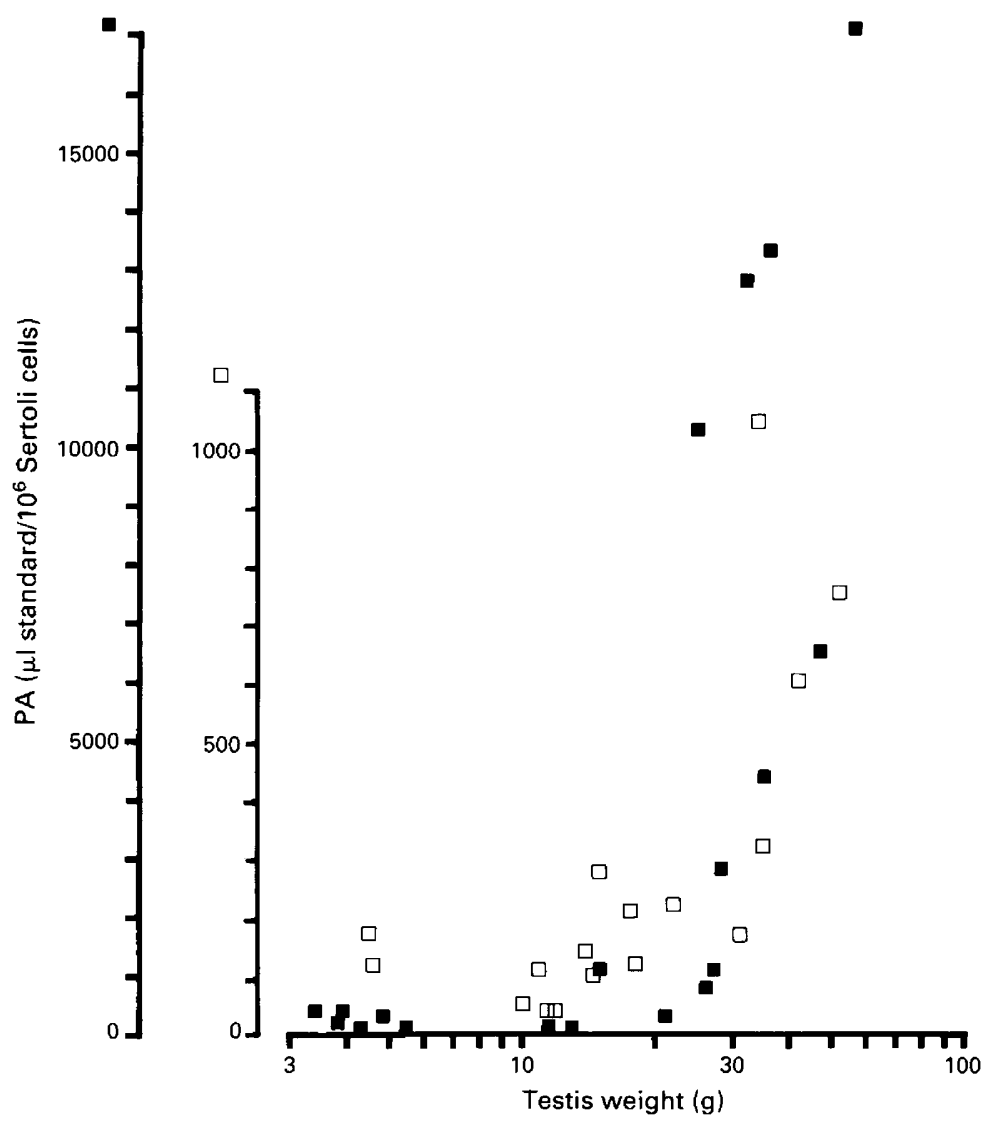

Fig. 8. Amplitude of the FSH-stimulated PA secretion (=maximal - basal) as a function of the testicular weight of piglets. FSH was added on Day $0(\boldsymbol{\square})$ or on Day $1(\square)$ of culture. Each point represents an animal. Note the logarithmic scale.

\section{Discussion}

Pig Sertoli cells could not be cultured when isolated from testes weighing more than $56 \mathrm{~g}$, i.e. when meiosis takes place. In mammalian species, the beginning of meiosis is accompanied by morphological differentiation of Sertoli cells, and particularly by the establishment of tight junctions (for review, see Tindall et al., 1985). This may render Sertoli cells less resistant to mechanical disruption during the isolation procedure.

The kinetics of PA secretion by pig Sertoli cell-enriched cultures under FSH stimulation was similar to that described by Lacroix \& Fritz (1982) in rat Sertoli cell cultures. It was quite different from the kinetics reported by Guillou et al. (1986) for rat Sertoli cell suspensions, in which a 2.5-h lag period was followed by a period of secretion that lasted only $2-2 \cdot 5 \mathrm{~h}$. 
The Sertoli cells of pigs exhibited a greater sensitivity to FSH for testes weighing $10-22 \mathrm{~g}$. This was not due to variations in Sertoli cell density, but to variations in the physiological stage of the piglets. A higher sensitivity to FSH occurred at the end of the non-pubertal period, which corresponds to the start of spermatogonial multiplication in this species. In the literature, there are only a few complete FSH dose-response curves at different ages. The dose dependency of FSH activation of adenylate cyclase has been tested in testicular membranes prepared from 12-and 55-day-old Sertoli cell-enriched animals (Van Sickle et al., 1981). In preparations from immature animals, the $\mathrm{ED}_{50}$ of FSH was about 3 times lower than in mature animals. Sketches of FSH dose-response curves were presented by Lee et al. (1983) for the monkey, showing age-related differences in Sertoli cell intracellular cAMP increases and in rates of aromatization of testosterone to oestradiol after FSH stimulation. The FSH sensitivity was greater in what they called "pubertal" animals (= rapid testicular growth period) than in younger "prepubertal" or older "adult" animals. Their observations and ours suggest that there is a critical time when increased FSH sensitivity is important for initiation of spermatogenesis. Then, during the prepubertal period, Sertoli cells become less sensitive to FSH.

In the male pig, serum FSH concentration averages $4.5 \mathrm{ng} / \mathrm{ml}$ between 8 and 12 weeks. Beyond 12 weeks, it remains relatively constant (7.66) until 24 weeks (Colenbrander et al., 1982). Sertoli cells in 1-4-month-old piglets are therefore fully capable of responding to the physiological range of FSH.

Pig Sertoli cell sensitivity to FSH was identical whether cells were stimulated on Day 0 or on Day 1 of culture. However, in 17-day-old rat Sertoli cells, sensitivity to FSH exhibited a 5-10-fold increase when cells were plated for $24 \mathrm{~h}$ as compared to the initial cell suspension (Guillou et al., 1986). Therefore, it appears that the use of trypsin for pig testicular cell isolation does not damage Sertoli cell FSH receptors.

Pig Sertoli cell-enriched cultures secreted 10 times more PA when stimulated with FSH on Day 0 than on Day 1. However, in 20-day-old rat Sertoli cells, the response to FSH in terms of PA secretion was larger when the hormone was added $24 \mathrm{~h}$ after plating than when added at time 0 (Lacroix et al., 1977). One explanation could be that pig Sertoli cells are much less viable on Day 1 than on Day 0 of culture.

In the piglet, the FSH-stimulated PA secretion increased sharply from a testicular weight of $25 \mathrm{~g}$ onwards, i.e. when primary spermatocytes appear. As in rat testis homogenates, PA levels increased at 9 days of age, concomitantly with the appearance of preleptotene spermatocytes (Vihko et al., 1986). Other approaches using isolated seminiferous tubule segments at different stages of the cycle of the seminiferous epithelium led to the conclusion that preleptotene spermatocytes upon their release from the basal lamina at the onset of meiosis are important regulators of PA secretion (Vihko et al., 1984).

This work was supported be a grant from INRA (ATP "hormones hypophysaires et fonction de reproduction chez les vertébrés.")

\section{References}

Colenbrander, B., Van de Wiel, D., Van Rossum-kok, C. \& Wensing, C. (1982) Changes in serum FSH concentrations in the pig during development. Biol. Reprod. 26, $105-109$.

Combarnous, Y., Guillou, F. \& Martinat, N. (1984) Comparison of in vitro FSH activity of equine gonadotropins (LH, FSH, and chorionic gonadotropin) in male and female rats. Endocrinology 115, 1821-1827.

Godinho, H. \& Cardoso, F. (1979) Sexual development of Yorkshire boars. II Onset and evolution of spermatogenesis. Arq. Escola de Veterinaria UFMG, Belo Horizonte 31, 351-361.
Guillou, F., Martinat, N. \& Combarnous, Y. (1986) Study of the superactivity of equine FSH in in vitro stimulation of rat Sertoli cells. Biochim. Biophys. Acta 887, 196-203.

Hennen, G., McNamara, M., Vandalem, J., Closset, J., Petit, R. \& Brooze, A. (1982) Ontogenesis of gonadotropin receptors ( $\mathrm{LH}$ and $\mathrm{FSH}$ ) during the neonatal period. In Ontogenesis of the Endocrine System (Coll. INSERM, Vol. 109), pp. 481-502. Eds J. Saez, J. Bertrand, J. Ducharme \& R. Collu. Editions INSERM, Paris.

Lacroix, M. \& Fritz, I. (1982) The control of the synthesis and secretion of plasminogen activator by 
rat Sertoli cells in culture. Molec. cell. Endocr. 26, 247-258.

Lacroix, M., Smith, F. \& Fritz, I. (1977) Secretion of plasminogen activator by Sertoli cell enriched cultures. Molec. cell. Endocr. 9, 227-236.

Lee, B., Pineda, J., Spiliotis, B., Brown, T. \& Bercu, B. (1983) Male sexual development in the nonhuman primate. III. Sertoli cell culture and age-related differences. Biol. Reprod. 28, 1207-1215.

Means, A., Dedman, J., Tash, J., Tindall, D., Van Sickle, M. \& Welsh, M. (1980) Regulation of the testis Sertoli cell by FSH. Annu. Rev. Physiol. 42, 59-70.

Parvinen, M., Vihko, K. \& Toppari, J. (1986) Cell interactions during the seminiferous epithelial cycle. Int. Rev. Cytol. 104, 115-151.

Smith, B. \& Griswold, M. (1981) Primary culture of supporting cells from bovine testes. In Vitro 17, 612-618.

Speight, A., Clifford, J. \& Waites, G. (1984) Protein synthesis by cultured Sertoli cells isolated from prepubertal lamb testes. In Recent Progress in Cellular
Endocrinology of the Testis (Coll. INSERM, Vol. 123), pp. 199-204. Eds J. M. Saez, M. G. Forest, A. Dazord \& J. Bertrand. John Libbey, Paris.

Tindall, D., Rowley, D., Murthy, L., Lipshultz, L. \& Chang, C. (1985) Structure and biochemistry of the Sertoli cell. Int. Rev. Cytol. 94, 127-149.

Van Sickle, M., Oberwetter, J., Birnbaumer, L. \& Means, A. (1981) Developmental changes in the hormonal regulation of rat testis Sertoli cell adenylyl cyclase. Endocrinology 109, 1270-1280.

Vihko, K., Suominen, J. \& Parvinen, M. (1984) Cellular regulation of plasminogen activator secretion during spermatogenesis. Biol. Reprod. 31, 383-389.

Vihko, K., Toppari, J., Saksela, O., Suominen, J. \& Parvinen, M. (1986) Testicular plasminogen activators during postnatal development in the rat. Acta endocr., Copenh. 112, 431-435.

Received 15 November 1988 